\title{
THE WATERS AND WATER SPIRITS IN VOTIAN FOLK BELIEF*
}

\section{Ergo-Hart Västrik}

\section{INTRODUCTION}

In this article I intend to focus on the belief reports, legends and descriptions of customs concerning the bodies of water and waterrelated supernatural beings recorded from the Votian linguistic area in the Votian language. ${ }^{1}$ As compared with the analogous Finnish (Jauhiainen 1998: 257-266), Estonian and Livonian material (see, for example, Loorits 1998: 111-210) the records of Votian folklore are scarce and relatively fragmentary, comprising a total of 120 shorter or longer texts. Except for a few from the 18th century, the era of the exploration of Votian folklore, the majority of accounts were collected by the greatest researcher of the Votian language of the 20th century, PaulAriste, an academician and professor of Tartu University. (These are available in the collection of manuscripts "The Votian Ethnology" and partially published in Ariste 1935; $1941 ; 1958 ; 1964 ; 1965 ; 1969 ; 1976 ; 1977$.$) In order to be able to$ orientate in this fragmentary material and categorise it in some way I will attempt to distinguish between the concepts reflecting the tradition spheres of different periods based on certain religious phenomenological processes as described by the Estonian historian of folk religion Ivar Paulson in his collection of essays "The Old Estonian Folk Religion” (1971).

Although the Votian linguistic area was relatively small during the collection period, we can distinguish between the preferences of different village groups as regards the names of the water spirits $^{2}$, beliefs and characteristic plots of folk narratives: particularly the Central Votia rich in lakes (the village groups of Orko, Mätši and Kabrio) contrasted with the western coastal villages and those at the River Lauga (the village group of Vaipooli and Kukkuzi; see map 1). The geographical position of the village groups has determined their different natural surroundings and sources of livelihood. Even in the middle of the 20th century people in Vaipooli gained their sustenance mostly from deep-sea fishing (the coastal 
villages had retained the common dragnet crews), whereas in Central and East Votia the smaller-scale fresh-water fishing had only a secondary role in providing subsistence (see Ränk 1960: 79). The difference is reflected correspondingly in the tradition concerning water spirits: in the Central Votian lake area the perception of water spirits was never associated with fishing, whereas in the villages of Vaipooli it was clearly a part of fishing at sea and in the River Lauga.

In the whole Votian area the names of water spirits refer to family relationships, particularly to maternal relations, and also to possession or ownership (containing the stem word haltiaz 'spirit', literally halta- 'to own', 'to rule'): for example, vesi-emä $\ddot{a}^{3}$ 'water mother', vesi-ämmä 'water woman'; jõgõõ-emä 'river mother', jarviemä 'lake mother', jarvi-isä 'lake father', järvõõ peremmeez 'lake master', jarvi-pappi 'lake priest'; vesi-haltiain, vesi-haltias, vesihaltialain all meaning 'water spirit', meri-haltia 'sea spirit', järvee haltiaz 'lake spirit', õjaa haltiaz 'stream spirit', lähte haltialain, lähtie altõo both meaning 'spring spirit'. The names of the water beings are distinguished according to their location in sea, river, lake, stream or spring, which is a manifestation of the belief that water spirits may inhabit every body of water. However, it is rather complicated to differentiate between the distinct categories of water spirits in the 20th century folkloric material on the basis of terminology. Below I intend to observe the water related tradition

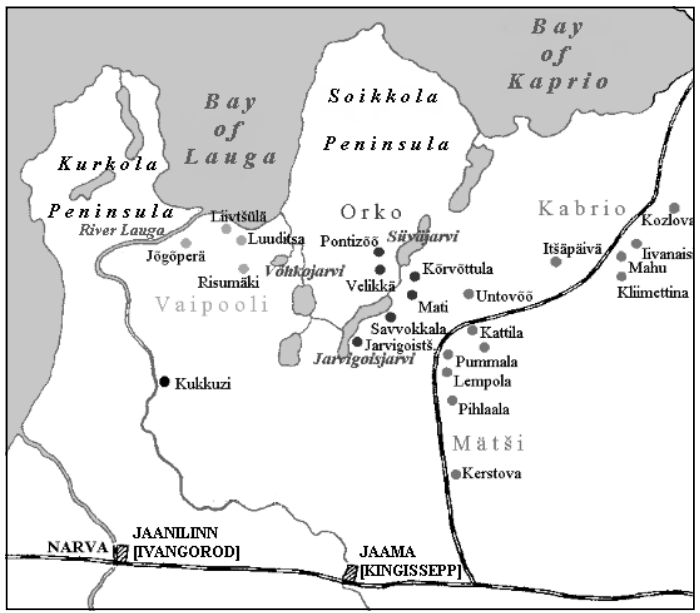

Map 1. Votian villages and village groups. 
as a set of clusters concentrated around a specific domain of interest, focusing mainly on ritual performances and their ways of interpretation.

\section{FISHING: FEMALE DEITIES, MASTERS OF THE UNDERWATER AND GUARDIANS OF FISH}

Similar to the tradition of other Baltic-Finnish and more distant kin peoples, the Votian tradition includes the notion of water spirit as a patroness of fish and mistress of the underwater. An 18th century account by the first investigator of Votians Friedrich Ludolph Trefurt, ${ }^{4}$ the Baltic-German pastor from Narva, states that the Votians had devoted one day in the year for the "goddess of the sea and rivers", the name of which Trefurt translated as Seemutter:

On this holy day everyone goes at midnight to the seashore. If they have gathered together, they all attire themselves in white and pray for a good and plentiful catch; in exchange they vow to give back the first fish caught to the Sea Mother after it has been cooked. Then they go back to their homes. Early the next morning they start fishing for the first communal catch of the year, cook the first fish at the shore and throw it back into the sea; there upon they fish for the whole day and at the end of the day are quite exuberant, especially if the haul has been successful, and they entertain themselves with excessive eating, drinking, singing and playing bagpipes as they used to do on St. Florus' Day. ${ }^{5}$ (Trefurt 1783: 18-19).

A similar description of water spirit cult has been recorded at the beginning of the 1790's by the Russian historian Feodor Tumanski in his description of the St. Petersburg Guberniya (Pronvince). ${ }^{6}$ According to Tumanski the Votians worshipped the "goddess of the waters, lakes and rivers" called Alteas on St. Elijah's Day (July 20th/ August 2nd). Similarly to Trefurt, Tumanski mentions the festive clothing of the participants, the gathering to a nearby lake, or a river or stream, the praying in the evening for a successful haul, the cooking of the first fish caught the next day, and joyous festivity (Öpik 1970: 112). We could, however, point out one difference: namely, according to Tumanski, the fishing began only after the service in the afternoon, adding that: 
The very same day they have a custom to ask a priest to sprinkle holy water on their cattle and sheep. They believe that the very year they stop performing that ritual their cattle will not increase and the fishing will not succeed. (Öpik 1970: 112).

Thus, we might assume on the basis of Tumanski's text, that the collective sacrifice of the first fish described above was, at least in some areas, associated with Christian church practice and the saint's day. Nevertheless, it is more likely that such a joint sacrificial ritual was held in spring, and not on St. Elijah's Day as Tumanski describes it. The reference to a goddess(es) here is a characteristic interpretation of the 18th century scholars: both emä 'mother' as well as (h)altias 'spirit' compounds are clearly related to the 19-20th century water spirit tradition, whereas Trefurt's term Seemutter might be identified as the vesi-emä or vesi-ämmä of the Vaipooli villages. One of the most important elements of the ritual is the white or festive clothing of the participants which has also been mentioned by Trefurt (1783: 22) in connection with magic and sorcery, and which has been described in even more recent accounts of sacrificial customs (see below). Another significant fact is that, according to the scholars, the joint sacrificial ceremony of the community was performed to obtain a good fishing catch and general well-being. The 19th and 20th century folkloric reports certainly contain references to sacrifice but the meanings attributed to ritual performances are associated with other spheres of life.

The respect towards the sea and supernatural beings in it is also reflected in the behavioural standards which prohibited swearing and quarrels during fishing (Ariste 1965: 431). The tradition related to fishing includes accounts recorded in the 20th century which say that a water spirit could impede the haul of greedy fishermen by tearing the fishing net or obstructing the fishermen in pulling the nets out. In some cases sacrifice is mentioned in connection with saying charms for the water spirit stressing the "do, ut des" idea:

Meez meni ühell oHtogoll. Pani võrkod järvee. Oomnikoll tämä sai pal'l'o kalaa. Saatii tšülää inimezet täätää, ett tämä sai pal'l'o kalaa. Jott Joro sai pal'l'o kaloi. Ja pantii tõizõd mehed võrkod vettee. Oomnikoll mentii võrkkoi võttamaa. Eväd võrkkoi 
tšättee saanõõD. - “Anna võrkod vällää, õo nii üvä. Mü annamm sillõõ musaa katii pää palkkaa!” - Eb antanud võrkkoi vällää. Jaa nii need võrkod jäiväD. Meni kaHs nätelii, ku mentii võrkkoi kattsomaa. Sis saivad vällää. Se mokoma vesihaltialain.

A man went out one night. Cast nets into the lake. In the morning he got a lot of fish. Village people found out that he caught a lot of fish. That Joro [=name of the fisherman] caught plenty of fish. So other men cast their nets into the water. The next morning they went to pull out the nets. They could not pull them out. - "Please, be so kind and give us back our nets. We will pay you with the head of a black cat." - She did not give the nets back. And so the nets were left in the lake. Two weeks passed and they went to see the fishing nets. Then they could pull them out. It was some kind of a water spirit. (VE VIII 199-200 < Jõgõperä, Darja Lehti (1938) = Ariste 1941: 48-49).

Throwing the head of a black cat into the water might be regarded as a placatory offering by addressing the water being and promising an offering in return for a good catch. A similar preventive magic ritual, a remnant of the sacrifice tradition, was also known in the villages on the banks of the River Lauga where people, before going to sea, had a custom of casting a small stone into the water (Ariste 1965: 431).

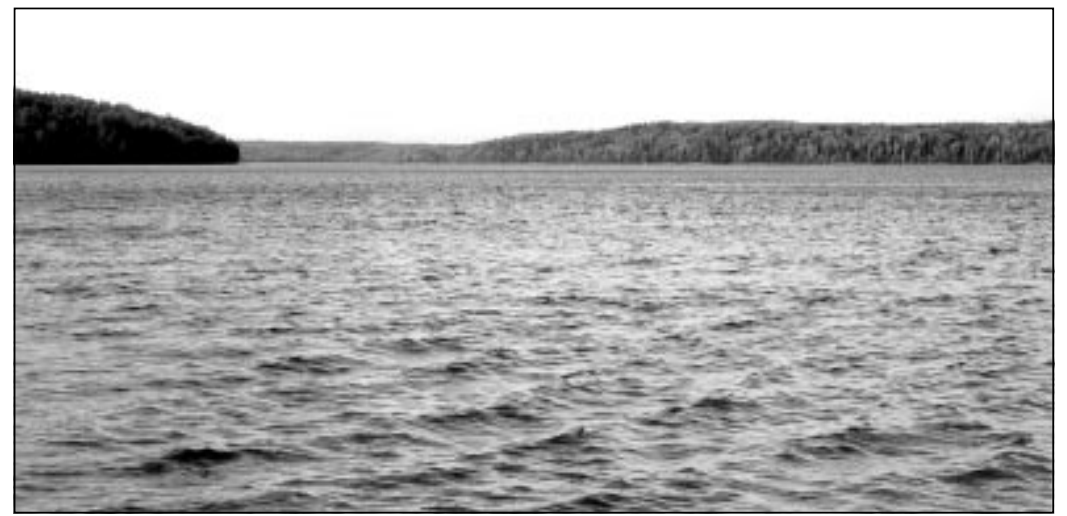

Photo 1. Lake Süväjarvi. Photo by Ergo-Hart Västrik 1998. 
A single account from Liivtšülä village (VE XIX 14) lets us know that getting lost at sea was interpreted as the interference of a sea spirit. Another interesting contamination of popular beliefs occurs in a report where the water spirit was identified as a hobgoblin who knew when the vessel would sink (VE III $141<$ Luuditsa).

As compared to the tradition of the Central Votia, the texts recorded from West Votian coastal villages contain but single references to the appearance and typical activities of water spirits. Nevertheless, I will introduce them, simultaneously pointing out the different possible associations. For instance, sea spirits (vesi-ämmä, meri-haltiaz) were believed to have the power to create waterspouts and capsize ships and boats (VE IX 195 < Luuditsa; Ariste 1958: 35). In these cases the water spirit has been also described as a huge fish or some other aquatic animal. A water creature's appearing in the shape of a fish might suggest its affinity to the guardian spirit of fish, however, in the scanty recorded material such reports are associated not with fishing luck but rather with accidents at sea. Another popular shape for a water spirit is half-human/ half-fish, also known through a migratory legend about a water spirit who became entangled in the net and bowed to the fishermen who had set it free before disappearing (cf. Jauhiainen 1998: L 56, L 234; Loorits 1998: 183-184 (S.27)). In the Livonian and Estonian folklore the narrative is connected to the pharaoh's children, in the Votian variant the fish-tailed being is not specifically determined:

Siso juttõli sitä viisii. Tämä nätši, ku tõmmattii nootaakaa. Naizelokaz õli, kalaa äntä õli. Üläpool õli inemiin, a alapool õli kala. Soomusõt pääl i kalaa äntä. I siis ko tämä tõmmattii maal, tämä kui ep tahtonnu. Siis takaaz lastii vettee. Tämä siis kummõrtõli, pääkaa kummõrtõli. Ännääkaa ku hloppaz, nii meni. Se õli kasin Ust-Naroovaz. Pal'l'o voosii on jo, ko õli. Siso õli herroill piikan. Siiš tšäütii kõik kattšomõz.

My sister told me this. She saw when the seine was hauled in. It was a female, had a fishtail. Her upper part was human, lower was fish. Had scales and fishtail. And when they pulled her ashore she did not like it. Then they released her back to the water. Then she bowed. Bowed her head. Flapped her tail as she went. It happened here in Ust-Naroova [=name of the set- 
tlement]. Many years have passed since. My sister worked as a maid for the gentry. Everybody went to see her [the sea creature] then. (VE XII 267 < Luuditsa, Paro Dmitrijeva $(1969)=$ Ariste 1977: 152).

\section{DROWNING: GENII LOCI, DEMONS AND DIDACTIC STORIES FOR CHILDREN}

Narratives focusing on water spirit as demonic drowner occur in numerous variants in Votian folklore. Such focus is mainly characteristic of the tradition associated with the Central Votian lakes, still it is known in Vaipooli villages and in East Votia.

In these beliefs the feminine aspect is also prevalent, which is suggested by the specific terminology as well as the description of the water spirit's outward appearance. Votian tradition, however, contains no elaborated legend types (fabulates according to Wilhelm von Sydow's terminology) about water spirits. The water spirit as an empirical supernatural being could be perceived for only a short period of time: a criterion for the supernatural is the sudden disappearance of an anthropomorphic being, particularly when an observer happens to expose its proximity. References to the places where spirits were most often seen or were believed to live are more general. Such places in bodies of water could be, for example, sites where water suddenly swirls upstream, sites with a deep bottom or those where people had drowned. Although the time of the water spirit's appearance is often unspecified we should note that in several reports and memorates the supernatural event has taken place at high noon:

Pajatan ize enes, mitä millõõ tapaHtu nuorõn pojon. - Menen ühskõrt Kattilalõõ. Se õli süäpäiväl. Menem mie kanvaa rantaa müö. Litši kalmoi õli lähe. Mie vaatan: meneb inehmiin, dai duumaan: meneb vetta juomaa läнtiess. Tulõm mie litšipäälie, inehmiin häviz. Vaatan üнtiep-puolõõ, tõisõõp-puolõõ, vaatan: tämä isub läнtie servää pääl da sugõp päätä. Mie seizattuzin dai vaatan i tšöhätin vai aivassiin. Dai hävis se inehmiin. Mie menin, tšä̈̈zin Kattilal i tulin kotuosõõ tagaaz. Pajatan mamalõõ, mitä mie näin. Mama juttõõ B: se õli läHtie altõõd vai altõõ. Mama juttõ̃ón, etti tšehsi-päiväll nävät tagottavad 
nä̈̈ttä̈̈ssä. "Mie tuozh õlõn nähnü. Mille tuli vassaa dai kõrraz häviz. Tuoš senes samaz läHtiez näin.”

I will tell what happened to me when I was a young boy. - Once I went to Kattila [=the name of the settlement and manor], it happened at high noon. I walk along the channel. There was a spring near the cemetery. I see: there goes a person, and I think: they must be going to drink water from the spring. I went closer, the person disappeared. I am looking to the right, then to the left and then see: they are sitting at the shore combing their hair. I stopped and looked at them and coughed or sneezed. And the person disappeared. I went to Kattila and then returned home. I tell my mother what I saw. Mother says: it was the sprite or spirit of the stream. Mother says that they usually appear at high noon. "I have seen them too. They came towards me and then disappeared. I saw them in the same spring as well." (VE IV 18-19 < Vanaküla < Pummala, Grigori Kuzmin (1932) =Ariste 1935: 10-11).

One of the commonest shapes for a water spirit is a woman with exceptionally long and dark hair, often sitting on a rock near a body of water or at the very edge of water, combing her hair, crying or lamenting. More detailed descriptions mention a silk scarf or a white shift as the characteristic attribute of a water spirit. A few accounts refer to the fishtail of anthropomorphic water spirits but this shape, though extremely popular in the Russian tradition (Vlasova 1995: 93), is not very common in Votian tradition.

Still, we cannot argue that the Votian water spirit tradition is restricted to female shapes only. The legends recorded in the Central Votian villages around Lakes Jarvigoisjarvi (also called Savvokkalaa jarvi, Baabinoi jarvi, Russian Babinskoye ozero) and Süväjarvi (Russian Glubokoye ozero) in particular, say that Lake Jarvigoisjarvi is the home of a female spirit ${ }^{7}$ and Lake Süväjarvi the domain of a male spirit. A popular belief about both lakes is that the spirits living in them drown people from the opposite sex, that is, only men are drowned in Jarvigoisjarvi and only women in Süväjarvi. A single text about the dialogue between the male and female spirits confirms their co-existence enabling us to speculate on certain family relationships between the different genii loci in the waters (see VE I 211 < Kõrvõttula, Ignati Smirnov (1942) = Ariste 1964: 169; 
1977: 153). The differences between male and female spirits are not, however, portrayed in any greater detail in the 20th century folklore. Often the corresponding tradition is rendered as a mere recognition of the existence of water spirits of different gender:

No vot, ved' juõllaz, etti jõka jarvez on õma emä, i õma isä. Vot jaa, en tä̈̈, Jarvigoiz-jarvõz, miltin siällä on, naiz-eläjä vai. Kuza-libo on meez-eläjä. A Süväjarvõz on meez-eläjä. Etti on kase, ettibõ on. Vot, meill ôli mokom konsti. Kupol'oo päivällä mentii, no, vennekaa - ebõll vene, taitaa mokom kori õli-mentii liukumaa. Kahõsaa entšiä $i$ garmoniikaa, se noorizo. Jaa. I vot, mokomaa lauluukaa mentii kottoa, illookaa mokoma. I kui nävät siäll mentii kukõrpalloa. I vot nellää entšiä, nii ebi saatu jarvõssa vällää. Ep saatu - eв, ep saatu. Mõnikkaat saatii, vot, izze tultii. Kummad ujuttii, kummat kui. A vot, näitä ebi levvettü. Ühellä emällä kahs poikaa. Jaa siz ühell i tõizõlla tüttered. Jarvi-emä upotti.

Well, you see, they say that every lake has its own mother, and its own father. You see. I don't know which is there in Lake Jarvigoizjarvi, a female? There is a female somewhere. But in Lake Süväjarvi there is a male. So it is the way it is. We did this trick, you know. On Midsummer's Day people took, well, a dugout boat - wasn't even a boat but I guess some kind of a dugout - and went onto the lake. Eight souls and an accordion, the youth. Yes. And you see, they were singing and having such fun when they went. And somehow they capsized the boat. And you see, four souls were not found and pulled out. Were not. No, were not. Some were, you see. Came out themselves. Whoever could swim, any way they could. But you see, they were not found. Two sons of one mother. Yes. And then two daughters of different mothers. The lake mother drowned them. (VE XVII $265<$ Mati, Maria Boranova (1974) = Ariste 1977: 154-155).

The abundance of memorates, recorded in the 20th century, prove the widespread acceptance of associating all kinds of water fatalities with water spirits. In addition often just a simple statement that the water spirit drowned, or took the person who drowned, is made (VE II $8<$ Savvokkala, Jevdokia Ivanova (1956)). More detailed accounts of what happened to the drowned person or his soul after his death have not been recorded in the tradition. Still, 
this might be associated with the gender differentiation of the drowned discussed above.

The seeing or hearing of a water spirit is most often interpreted as an omen for the imminent water accident and drowning. According to the legends water spirits make sounds and appear sitting on rocks at the shore with the purpose of luring curious passers-by towards water (see, for example, VE II $75<$ Mati, Olga Ivanova (1959) = Ariste 1964: 170; VE XVI 141-142 < Liivtšülä, Nadjozha Leontjeva (1973)). It also introduces the idea of predestination: people believe that the water spirit drowns at a certain predetermined hour (VE I 140 < Mati < Jarvigoistšülä, Avdotja Onufrijeva (1942) = Ariste 1977: 153-154). Furthermore, some bodies of water are associated with a belief that every year an animal or a human will drown in it if the sacrificial ceremony is not performed at the customary time (most commonly in spring). Interestingly enough, the latter idea has been a basis for justifying the necessity of water sacrifice in Ingria. This is, for example, how the sacrifice of a ram or its head and feet to a creek at the River Lauga near Kotko village on St. Elijah's Day has been interpreted:

Kutsuttii umpi-apaja. Ku Iilää praaznikka tuli, sis tapõtti boranoi ja veetii apajaa. Vizgattii sinne: "Naнн, sü̈̈ boranaa päit, elä sü̈̈ in'emisii!” Kotko tšüläzä õli riigoi takan. Ühs kaHtšümmed virstaa õli Jõgõperält Kotkoosõõ.

It was called a creek. For St. Elijah's celebration a ram was slaughtered and taken to the creek. It was cast in there: "Here, eat the ram heads not people!" At the village of Kotko it was behind the threshing barns. There was nearly 20 verst [21,3 kilometres] from Jõgõperä to Kotko. (VE VIII < Vanaküla < Jõgõperä, Darja Lehti = Ariste 1941: 64) ${ }^{8}$

Here again the charm has an important role in sacrificial ceremony - it as if increases the significance of the performance and guarantees its reaching the right addressee. A similar sacrifice was performed at a shallow place rich in springs (lähtie silmä 'the eyes of springs') near the village of Pummala in springtime in order to prevent the cattle drowning:

Õli enne vanall aikaa med'd'ie tšüläzä pienez orgoza ühs mokomain paikka, kuhõ ain iezepii lehmäd da lampaad 
vajozivad da uppozivad. Eb mennü sitä tševättä, ko sinne paikkaasõõ eb upponnu lehmä vai lammas vai opõnõ. Senie paikaa nimi ôli lähtie silmäD. Tõukattii sinne kõm sült ruiku $i$ põhja ep saatu. Vanad iniehmiizet kõik koppiuzivat kokuosõõ $i$ duumazivat tšehsinää, etti mitä mü̈ nõizõmma tetšemääsie, ko se lähtie silmä jeka vuosi võtab meilt opõzõõ vai lehmää vai lampaa. Näväat siz duumazivad, etti müö lupaamma sinne lähtie silmälie ühie boranaa. Õsamma tšülääkaa jeka tševäd ühie boranaa, ko maa sulaв. Siz lõikatazz boranalt pää õtsass vällää i laskõass sihiesie lähtie silmääsie koko borana i juollass: "Vot sillõõ suvõõ toitto!” Sis tullass vällää. Tšülääkaa lagottaass mügrää nõsõtut pezäD. Sis tullass tšülääsie. Lagotõttii mügrää pezät senie perääss, etti õlõissi parap einää lüvvä $i$ evät kazvaiss mättääd niitüü päälie. Tšülää selskõi annap tšülä̈̈ dengoi $i$ ossaass puol pankõa viinaa. Juvvass, pitääz boranalõõ pominkat tšülääkaa ühez. I nii jeka tševäd lõikattii borana $i$ lagotõtti mügrää pezäD. Se ôli vanall aikaa, ko juoltii enne da ata.

In ancient times there was a place in a little valley of our village where cows and sheep used to sink and drown. No spring passed without a cow or a sheep or a horse drowning in this place. The place was called 'the eyes of springs'. They had poked a stake three fathoms long there and couldn't reach the bottom. Old people all gathered together and discussed what to do if this spring eye was going to take a horse or a cow or a sheep every single year. And so they thought that we would promise a ram to the spring. Every spring the village people would buy a ram, when the earth softens. Then the ram's head is cut off and the whole ram is cast into the spring, saying: "Here's the whole summer's food for you!" Then they leave the place. All the village people tramp on molehills. Then they return to the village. The molehills were tramped down for making the hay raking easier and to prevent the growing of sods on the hay field. The village elder gives the collected money and they buy half a bucket of vodka. The whole village drinks and celebrates the wake of a ram. And so every spring a ram was slaughtered and molehills tramped down. It was in old times when people saidenne 'mother' and ata 'father' [=used the old vocabulary]. (< Vanaküla < Pummala, Grigori Kuzmin (1932) = Kettunen \& Posti 1932: 97-98). 
The one to whom the offering is made is not mentioned, thus it is not clear whether the rite was performed for a water spirit or a personified body of water. The ceremonial nature of the village's collective sacrifice has a significant role, as a "wake" and trampling on molehills following it, whereas the narrator presents the genesis of the custom, which has obviously developed in a relatively recent period of time. Even if the tradition of sacrifice emerged in Pummala village as late as in the 19th century, such an interpretation must be based on patterns already existing in the tradition. Thus we will realise from the previous examples that sacrifice in water is indirectly related to good luck with the herd - a set of associations which is connected with other cases of water sacrifice (see, for example, Oinas 1985: 202).

People from villages around Lake Jarvigoisjarvi have also sacrificed to the female spirit living in the lake. Even as late as in the 19th century there was a tradition in the village of Jarvigoistšülä related to the St. Elijah's Day celebrations. That day villagers gathered at an old chapel site, brewed beer and slaughtered a ram or an ox for the communal feast, and the head of the animal was thrown into the lake as a "placatory offering" (Lukkarinen 1912: 49). ${ }^{9}$ Even in the 1960's it was still recalled in Kõrvõttula village that in the past people used to cast money and scarves into Lake Jarvigoisjarvi to please the jarvi-emä 'lake mother' (VE X 72-73 < Kõrvõttula, Jekaterina Jovleva (1966)).

Sacrificial rites, the time of performance and in a way also the methods used in ceremonies resemble the reports from Trefurt and Tumanski quoted above, still, the meaning attributed to the ceremonies differs considerably. The asking for luck with the catch recorded at the end of the 18th century is not mentioned in the reports recorded during the first half of the 20th century. During this period the sacrifice to water spirits/bodies of water is consistently interpreted as a rite preventing accidents on water.

One exceptional procedure preventing drowning, which evidently belongs to the Christian stratum of tradition, is described in an account of how a church elder swam upstream in the River Lauga, and after that nobody drowned there any more (VE XX 170-171 < Liivtšülä, Nadjozha Leontjeva (1976)). 
The somewhat negativistic mode of water spirit related beliefs has given reason to interpret the spiritual creatures in the waters as forms of the devil's appearance. The demonic beings called paha 'the Evil', meripaha 'the Evil of the sea',järvee paha 'the Evil of the lake' or vesihoono 'the Evil of the waters' were described as virile; a single more detailed description mentions its black beard (VE XVII 65-66 < Kukkuzi, Fenja Fedulova = Ariste 1977: 158-159).

As the bodies of water were first and foremost dangerous for small children it is not surprising that the stories about water spirits were told to scare children away from water. The short reports contain but few detailed descriptions (for example, their long, dark hair) about the nature and appearance of water spirits, and are mostly limited to a mere recognition that the water spirit takes or draws people into the water. Such didactic methods have probably been applied at different periods of time. The pedagogic function of water spirits appears to have persisted in tradition for the longest period of time, even when the more elaborated memorates and legends about water spirit as drowner have lost their topicality and have receded from the tradition.

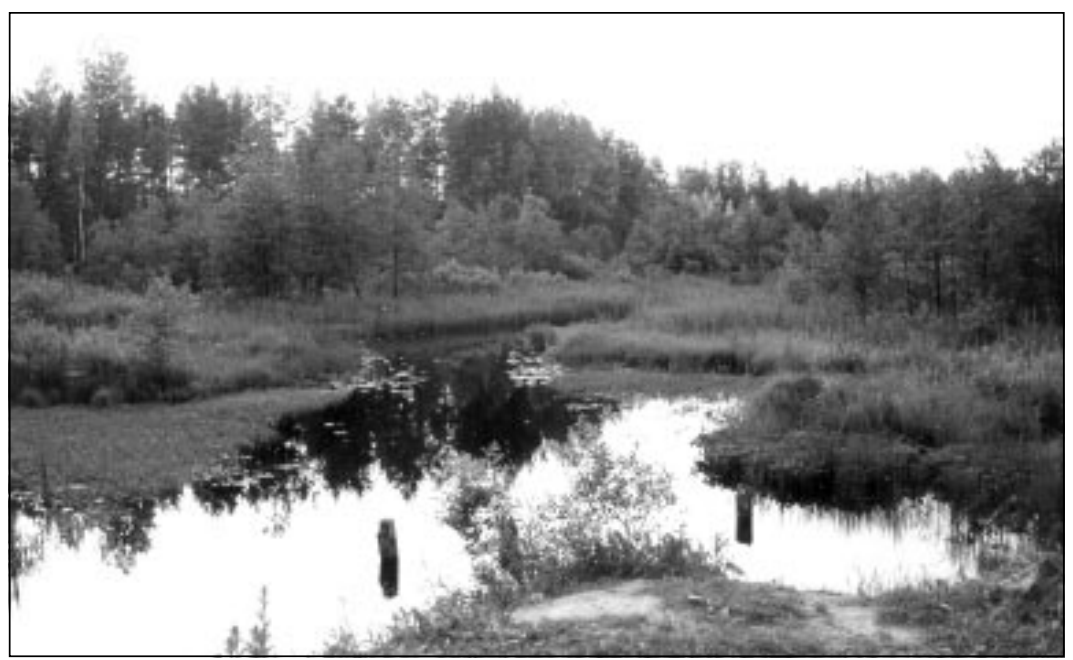

Photo 2. Site at River Tshämee [sh=s'] where water suddenly swirls upstream. According to the folk belief it was the place where resided water spirit ("jõggõ em em" or "vesi-emä"). Photo by Ergo-Hart Västrik 1998. 


\section{HEALING: ILLNESS FROM WATER, PERSONIFIED BODIES OF WATER AND SAINTLY MIRACLES}

The Votian tradition contains a single report concerning the water (or more specifically stream) spirit as a causer of illness:

Altias se on mokoma. Eittü̈̈d, tämä alpaab õjassa, alpaab maassa. Altiad ne alpaavad. Õiaa altiaad, ili suo altiaad, il'i metsää altiaad. Sinne vijjäs võraa. Altiaz võtti, vietii võra. Võra on mokomain: puhaz valkõa šiška. I sis kõm kopeikkaa d'engoi il'i kopeikka, vahtšizõd, i pannas sihee paikkaasõõ, kus on tullu. I kõm kõrtaa kummartaas mahaassaa. I ot'ši-naše lukõassa $i$ "Anna antõõs armas maa, i kalliz õja". Sis tullaas kotuo i tagaaz eb vaatahta. I kasõ tehäs iezä päivää nõisua, kiõs kõikii magataas. Etti tšenniid eb nätšeissi, tšennid ep täätäissi. I sis saap tervies. Mie näin mõnt altiaa, mõnõl viittä näüttääväd.

Spirits are like that. You get scared, it benumbs you in the stream, benumbs on the ground. Spirits - they paralyse you. The spirits of streams, or bogs or woods. People take offerings there. A spirit took something, an offering was given. The offering was like a clean, white piece of cloth. And then three kopecks of money or only one, all new ones, are dropped where it came from. And then people bow three times. And they read the Lord's Prayer and say "Forgive us, sweet earth and precious stream". Then they return home and don't look back. And all is done before sunrise when everybody's asleep. So that no one would see, that no one would know. And [the ill person] gets well. I have seen some spirits, they appear in various ways. (VE I 9-10 < Lempola, Solomonida Kuzmina (1942)).

The concept of illness caused by water (also by earth or wind) was well-known in Votian popular religion. More generally, it is connected to the custom of sacrifice into streams and springs still, according to the data we have, these rituals are usually not addressed to personified water beings.

One of the most typical healing procedures at springs was to wash the sick part of the body with spring water and to cast into the water a clean piece of cloth, towel or handkerchief, some salt, a coin or a piece of silver that had been held at the sick place and 
wrapped in the cloth. The sacrificial ritual was performed with bows and prayers, which included begging for forgiveness, promising offerings and asking for good health in return:

Siz veel õli kassõnn üli Tšämmee jõggõ̃ tšülmä lähe. Sinne toozhõ tšäütii, kummartõltii. I veetii võrad, tšell vaivattii silmiä. Silmärätti vai nenärätti puhaz, vassõn, senneekaa pühittii silmäD. Siz lahzõttii sinne tuulõõsõõ $i$ vetteesee. Tšüzüttii: "Anna antõõssi! Sillõ puhaz võra, a millõ üvvää tervüüttä!” - Ühsnä tšen peltšäzi mennä, nii tõin tuli niku dovarišassi. Pellättii semperäss, etti ain mentii perrää päivää laskua. Il'? oomniz varraa, ko päivä kohonõв, örtšähtääb ülleez. Päivä algab valgõta, jo valkõneb, siz eb mentü. Kunis tuli api, nii mõnt kõrtaa tšäüti. Entizell väellä ved'dohtorai bõllu. Siz ain tšäütii, tšen mitä õpõtaB, kuhhõõ tšävvä, laskõa võra.

At these times a cold spring current used to run on the other side of the River Tšäme. People went there, bowed. And those with sick eyes took offerings. A handkerchief for wiping eyes or nose, a clean and new one, they wiped their eyes with it. Then they let it go with the wind and fall into the water. And they asked: "Forgive us! A clean offering for you, good health for me!" - Those who were afraid to go alone took a companion with them. They were afraid because you had to go after the sunset. Or early in the morning when the sun rises, wakes up. The day gets lighter, if it did they did not go. And they went there as long as they got better. People in olden times had no doctors. Then they went to the people who taught things, where to go and where to take an offering. (VE IX $15<$ Mati, Maria Boranova).

Similar private sacrificial ceremonies were most commonly held at the springs and streams further away from villages which were considered extraordinary/sacred because they flowed "counter-clockwise" (sõizob vassoo päivä̈̈, vassa päivä virtaap 'flows counter-clockwise'; literally 'against the day'). In such cases the sacrificial ritual is addressed to a body of water, earth or wind but in most descriptions of customs, however, the association is not directly established. Thus in 20th century tradition such sacrificial rituals for healing and curing purposes form a category usually considered as separate from concepts of water spirits. And, apparently, the focus here 
is on the personified body of water and not personified supernatural beings.

Once again we might draw several parallels between the healing rites at springs, streams and wells and the 18th century accounts of Trefurt and Tumanski about the worshipping of "water goddesses". The time for performing rituals at smaller bodies of water was also fixed (taking place early in the morning before sunrise), the clothing specified (clean, white clothes), and, similar to Tumanski's account, the healing was partly combined with church practices. Holy sites were declared to be sacred by Christian priests, chapels were built near springs and the common ceremonies with a priest's participation were held on church holidays (see, for example, Pantshenko 1998: 70-179).

Healing with spring water and taking offerings into the nearby chapels (for donating to beggars) were often closely interrelated. For example, there was a custom to take a sheep's head and feet to the chapel in Pihlaala village on St. Anastasia's Day (October 29th/ November 11th) and to perform a healing rite at the nearby spring. In several cases the offerings were also taken to the spring:

Pihlaalaa tšüläsee lähteelee - nii üvä vesi õli-veetii võraata. Jutõltii: “Millõõ tervüüz, a sillõõ võra!” Pihlaalaa tšasovnalõõ veetii boranaa pääd ja jalgaD. Bednõilõõ jagõttii. Kerääjiilee jagõttii.

An offering was taken to the spring in Pihlaala village - the water was so good there. And they said: "Health to me, offering to you!"A ram's head and feet were taken to the Pihlaala chapel. Given to the poor. Given to the beggars. (VE I $93<$ Kattila PeenÕtsa, Antonina ja Irina Antonova (1942) = Ariste 1969: 131).

The Christian layers of worship related to the water was most prominent in the case of springs that were located on the precincts of villages or in their close vicinity. The popular names referring to saints given to the smaller bodies of water (for example, Kupul'oo kaivo 'Baptist's Well' in Kõrvõttula village, Iiliää õja 'St. Elijah's Stream' in Kattila, Sergei lähe 'St. Sergei's Spring' in Jõgõperä, Spaasaa lähe 'Saviour's Spring' in Kabrio) and the churches and chapels built nearby suggest Christian consecration. Therefore, the 


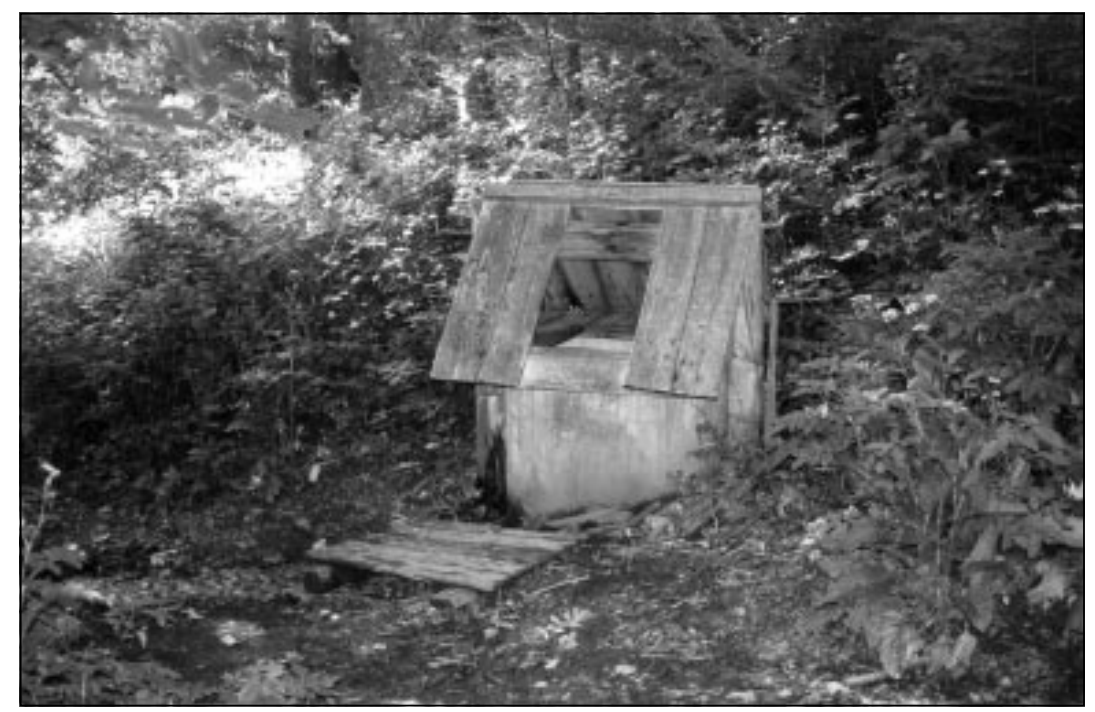

Photo 3. Spaasaa lähe in Kabrio. Photo by Ergo-Hart Västrik 1998.

cure obtained by healing with spring water has also been interpreted as a saintly miracle; thus the belief in the powers of water as a life-giver was mixed with beliefs related to Christian saints. Similarly, the supernatural incidents believed to have taken place near springs were thereby interpreted as saintly appearances, proven by holy images and the saints' footprints found nearby. (< Pihlaala, Filipp Grigorjev (1928-1929) = Lensu 1930: 274; VE I 25 < Lempola, Solomonida Kuzmina (1942) = Ariste 1977: 11; see also Västrik 1999: 182-197).

\section{CONCLUSION}

Observing the tradition of water spirits in Estonian folk religion Ivar Paulson (1971) argues that according to the religious phenomenology the guardian spirits of fish, mother of waters and images of animate, personified bodies of water are relevant for the fishermen's ecotype. The demonic water spirits are but characteristic of the beliefs of agricultural and cattle-breeding people. In a way the Votian water spirit tradition supports this theory, as the emphasis on tradition is different in the coastal villages around the Bay of Lauga and along the river on the one hand, and in the Central 
Votian lake region on the other where the economy was different up to the recent decades.

The tradition associated with the sea reveals the concepts of a feminine patroness of fish and the master of waters who possess the powers to influence the fishing haul and create waterspouts. Quite popular shapes of seawater beings are also a huge fish or half-man half-fish. Still, the number of recorded crystallised legend types focusing on such concepts is very small indeed. They have been preserved in tradition mainly in the form of short belief reports describing the water spirit and its characteristic behaviour.

According to the religious phenomenology the concepts about genii loci of different genders living in bodies of water might be considered as more recent ones; they were further elaborated to concepts of water spirits as malevolent drowners. Such beliefs were most characteristic of the Central Votian lake region. Even here the prevalent typical shape is of a female water being who was mostly described as a long-haired woman sitting at the edge of water, combing her hair and lamenting. Memorates and legends reveal that the water spirits as empirical supernatural beings could be perceived (audibly as well as visually) only for a short period of time and has often been taken as a prediction of someone's (mostly a village community member's) imminent death by drowning. The accounts where water spirits were identified as devils are an example of extreme demonisation. The pedagogic function of tradition related to water spirits (that is, references to them for the purpose of scaring children away from water) has apparently proved most enduring.

The ritual ceremonies addressed to water and water beings were most often performed to ask for a good catch, prevent drowning and other accidents on water and also for the curing of illnesses. The offerings can be categorised as the offerings of the first catch at the beginning of the fishing period, placatory offerings related to the risk of drowning but also to fishing, and preventive sacrifice performed for avoiding accidents on water. The typical behavioural patterns of sacrificial ceremonies (including charms) resemble one another considerably. It is also possible that, due to the changing emphasis in tradition, the rituals originally associated with fishing have acquired a different purpose to become rituals preventing 
drowning. The sacrifice in springs for healing purposes is somewhat exceptional as it is not associated with personified water beings. The accounts about smaller bodies of water do, however, suggest concepts of personified bodies of water. One of the reasons for such phenomenologically archaic remnants might be the integration of spring sacrifice into the official church practice, which helped to secure the uniformity of these ideas. The aspect of demonisation, therefore, became less prevalent when sacred springs were associated with the Christian cult of worshipping saints.

Translated by Kait Realo

\section{Comments}

"The article is based on the presentation delivered at the Conference of Young Folklorists held in the Estonian Literary Museum on April 14th 1998. I am most grateful to Fionnuala Carson Williams (The Institute of Irish Studies, The Queen's University of Belfast) for helpful suggestions and comments on the translation.

${ }^{1}$ The Votians are Baltic Finnic people on the verge of extinction, the last representatives of which are living in three villages in the Kingissepp district of Leningrad oblast (Arukask 1998: 7). For more details about the ethnic history of Votians, as well as the study of Votian folk belief, see Viikberg 1993, Västrik 1999: 173-178. The toponyms used in the article follow the Votian or wider Balto-Finnic usage.

${ }^{2}$ The term 'water spirit' used hereafter denotes all the supernatural beings associated with water and bodies of water.

${ }^{3}$ The Votian terminology and examples in the article are presented in the simplified transcription of Votian dialectal texts, based on linguistic principles introduced in the preface of the Votian Language Dictionary (VKS 1990: 14-17). The Roman numerals in references to the original manuscripts of Paul Ariste designate the volumes of the collection "The Votian Ethnology" (VE), the Arabic numerals refer to the pages. In most cases the home villages and names of informants were included. 
${ }^{4}$ Trefurt visited Kattila manor probably in the beginning of 1780's where he came across the language he "had never heard before" (Trefurt 1783: 10). His key informant in Kattila was Votian woman who "spoke not only perfect Russian but also quite good German" (ibid.: 11).

${ }^{5}$ St. Florus' Day (Chlarinstage in Trefurt's study) is celebrated on August 18th or, according to the Gregorian calendar, on August 31 th. Belonging to the sphere of the Russian Orthodox Church Votians follow church calendar dates according to the old style Julian calendar. For the descriptions of the celebration of St. Florus' Day, see Trefurt 1783: 15-18, Ariste 1969: 116-121.

${ }^{6}$ Tumanski visited Kattila manor and/or some of the Votian villages nearby in his short field trip in 1790. Data about Votians (and Izhorians) in his manuscript became available for researchers in 1970 when parts of Tumanski's work with Estonian translation were published (see Öpik 1970).

${ }^{7}$ According to popular etymology the village of Jarvigoistšülä (Baabina) was named after the female spirit (for more details see Lukkarinen 1912: 49, Ariste 1964: 170). This appears to be the only place-name connected with water spirits.

8 The sacrificial rite at Kotko village has been more thoroughly described by Felix Oinas (1985). In Kotko the sacrifice to the water spirit (jokiämmä, merenhaltei, huonoi, kirlouks) was integrated into church practice: a small wooden chapel was located near the sacrificial site, the ceremony was conducted by a priest. The Christian background is reflected in the word "Kirlouks!" said out loud during the ceremony, which most likely is the Old-Russian counterpart for the priest's "Kyrie Eleison" (ibid: 205).

${ }^{9}$ A somewhat different account of the origin of sacrificial traditions is described in the legend from the Izhorians of Soikkola peninsula recorded by J. Lukkarinen:

Once the villagers of Jarvigoistšülä promised the spirit of Jarvigoisjarvi a human head every year for better catches. The sacrifice was performed for many years until a smart man took a cow's head to the lake, explaining that it was never specifically determined what head it had to be. From then on the spirit 
had to be satisfied with the cow's head. (Lukkarinen 1912: 4849).

The story told thus is most apparently a fictional explanation of the people from neighboring parishes about the custom of water sacrifice into Lake Jarvigoisjarvi. The sacrifice of a human head might be regarded as a contamination of different elements: combining the motifs of the legend saying that every year someone was drowned in the lake, and the knowledge of sacrificing an animal's head in Lake Jarvigoistšülä. (It might also be caused by misinterpretation. Cf. for example, the expression used for drowning: Ain võtab inemizee pä̈̈ sinne 'takes the person's head there'.)

\section{References}

Ariste, Paul 1935. Wotische Sprachproben. Opetatud Eesti Seltsi Aastaraamat 1933, pp. 1-85.

Ariste, Paul 1941. Vadja keelenäiteid. Mit einem Referat: Wotische Sprachproben. Tartu.

Ariste, Paul 1958. emä ja isä vatjan kansanuskossa. Kalevalaseuran vuosikirja 38, pp. 29-38.

Ariste, Paul 1964. Baabino ehk Jarvigoištšülä. (Ühest vadja külanimest.) Emakeele Seltsi Aastaraamat X, pp. 167-171.

Ariste, Paul 1965. Vatjalaisten vesiämmä. Virittäjä, s. 430-431.

Ariste, Paul 1969. Vadja rahvakalender. Emakeele Seltsi Toimetised nr 8. Tallinn.

Ariste, Paul 1976. Vadja järvehaldjas vezikko. Emakeele Seltsi Aastaraamat XXI, pp. 95-98.

Ariste, Paul 1977. Vadja muistendid. Emakeele Seltsi Toimetised nr 12. Tallinn.

Arukask, Madis 1998. Death and Afterwards. Folklore. An Electronic Journal of Folklore, Vol. 8. http://haldjas.folklore.ee/ folklore/vol8/mds.htm

Jauhiainen, Marjatta 1998. The Type and Motif Index of Finnish Belief Legends and Memorates. FFC 267. Helsinki.

Kettunen, Lauri \& Posti, Lauri 1932. Näytteitä vatjan kielestä. Suomalais-ugrilaisen Seuran Toimituksia LXIII. Helsinki.

Lensu, Y.Y. 1930. Materialy po govoram vodi. Zapadnofinskii zbornik. Leningrad.

Loorits, Oskar 1998. Liivi rahva usund I-III. Tartu. 
Lukkarinen, J. 1912. Inkeriläisten praasnikoista. Suomalaisen kansanrunousseminaarin julkaisuja II. Helsinki, pp. 37-91.

Oinas, Felix 1985. Ingrian Kirlouks "Water Spirit". Studies in Finnic Folklore. Homage to the Kalevala. SKS Toimituksia 387. Mänttä, pp. 201-211.

Pantshenko, Aleksandr Aleksandrovich 1998. [Narodnoe pravoslavie.] Issledovanie v oblasti narodnogo pravoslavia. Derevenskie sviatyni Severo-Zapada Rossii. Sankt-Peterburg.

Paulson, Ivar 1971. The Old Estonian Folk Religion. Indiana University Publications, Uralic and Altaic Series 108. Bloomington.

Ränk, Gustav 1960. Vatjalaiset. Suomalaisen Kirjallisuuden Seuran Toimituksia 267. Helsinki.

Trefurt, Friedrich Ludolph 1783. Von den Tschuden. Fr. K. Gadebusch (ed.). Versuche in der livländischen Geschichtskunde und Rechtsgelehrsamkeit. I Band, 5. Stück, Riga, S. 1-28.

$\mathrm{VE}=$ the manuscript collection of Votian ethnology (I-XXIII) by Paul Ariste in the Estonian Folklore Archives.

Viikberg, Jüri 1993. Vene impeeriumi rahvaste punane raamat. Tallinn.

In English: http://www.eki.ee/books/redbook/votes.shtml

VKS 1990 = Vadja keele sõnaraamat $\mathrm{I}$. Toim. ElnaAdler ja Merle Leppik. Tallinn.

Vlasova, M. N. 1995.Novaia ABEVEGA russkikh sueverii. SanktPeterburg.

Västrik, Ergo-Hart 1999. The Legends of the Ilyosha Village Chapel in Votian Folk Tradition. Ülo Valk (ed.). Studies in Folklore and Popular Religion. Vol. 2. Papers delivered at the Symposium Christian Folk Religion. Tartu, pp. 173-207.

Öpik, Elina 1970. Vadjalastest ja isuritest XVIII sajandi lõpul. Etnograafilisi ja lingvistilisi materjale Fjodor Tumanski Peterburi kubermangu kirjelduses. Tallinn. 